\title{
Methane emissions from wetlands, southern Hudson Bay lowland
}

\author{
T. R. Moore and A. Heyes \\ Department of Geography and Centre for Climate and Global Change Research, McGill University, \\ Montreal
}

\section{N. T. Roulet}

Department of Geography, York University, North York, Ontario, Canada

Methane emissions were measured by a static chamber technique at 39 sites along a transect from the James Bay coast at the southeastern tip of Hudson Bay to Kinosheo Lake, northwest of Moosonee, Ontario, Canada. These sites represented five major wetland ecosystems along a successional gradient from the coast inland. Measurements were made at $\approx 10$-day intervals from early June to mid-August, and once in mid-September and mid-October 1990. Seasonal $\mathrm{CH}_{4}$ fluxes were small $\left(<2 \mathrm{~g} \mathrm{~m}^{-2}\right)$ at the recently emerged coastal marsh, coastal fen, tamarack fen, and interior fen ecosystems, except where there were shallow ponds and pools, which emitted 2 - $5 \mathrm{~g} \mathrm{CH}_{4} \mathrm{~m}^{-2}$. At the more complex bog ecosystem locations, $\mathrm{CH}_{4}$ fluxes were small $\left(0.3-2.0 \mathrm{~g} \mathrm{~m}^{-2}\right)$ from hummock/hollow microtopography in the raised bogs and from the forested margin. The largest $\mathrm{CH}_{4}$ fluxes were recorded from the degrading peat sections forming shallow pools and the moss/sedge mats which were always close to saturation $\left(1.8-16.6 \mathrm{~g} \mathrm{~m}^{-2}\right)$. A deeper (1-m water depth) pool emitted less $\mathrm{CH}_{4}(1.4 \mathrm{~g}$ $\mathrm{m}^{-2}$ ). In terms of ecological succession along the transect, covering emergence over $\approx 4000 \mathrm{yr}, \mathrm{CH}_{4} \mathrm{emission}$ rates increase from marsh to fen and bog, primarily through the development of peat degradation and the formation of moss/sedge lawns and pools. There were very weak statistical relationships at each site between the daily $\mathrm{CH}_{4}$ flux and peat temperature and water table. However, there was a significant $\left(r^{2}=0.44, p<\right.$ 0.001 ) correlation between the seasonal $\mathrm{CH}_{4}$ flux and the mean position of the water table over the complete range of sites, emphasizing the overall importance of hydrology in determining $\mathrm{CH}_{4}$ flux. Laboratory incubation experiments were conducted to determine the capacity of the surface $(0-20 \mathrm{~cm}$ depth) peat samples to produce $\mathrm{CH}_{4}$ anaerobically and consume $\mathrm{CH}_{4}$ aerobically. They revealed that many samples exhibited high $\mathrm{CH}_{4}$ consumption rates, suggesting that although $\mathrm{CH}_{4}$ production in the subsurface peat is high, $\mathrm{CH}_{4}$ emissions from these wetlands to the atmosphere are limited to a large extent by $\mathrm{CH}_{4}$ oxidation in the surface layers of the peat. Trophic status of the peat appeared to have little influence on emission rates, with the highest fluxes in the most acid $(\mathrm{pH}<3.5)$ samples.

\section{INTRODUCTION}

Current global methane budgets estimate between 22 and $70 \mathrm{Tg}$ $\mathrm{CH}_{4} \mathrm{yr}^{-1}$, or 4 to $16 \%$ of the annual atmospheric burden, is emitted from wetlands north of $40^{\circ} \mathrm{N}$ [Aselmann and Crutzen, 1989; Fung et al., 1991; Matthews and Fung, 1987]. This wide range in possible source strength results from the lack of measurements of $\mathrm{CH}_{4}$ flux from such large areas $\left(\approx 3.0 \times 10^{6} \mathrm{~km}^{2}\right.$ [Aselmann and Crutzen, 1989]), the diversity of wetland types in any one region and the poor knowledge of the areal extent of any one wetland type. Compounding the problem of obtaining regional estimates of $\mathrm{CH}_{4}$ emissions is the large intrasite and intersite spatial variability in $\mathrm{CH}_{4}$ flux, even within wetlands that are classified as ecologically similar [Bartlett et al., 1992; Moore et al., 1990; Morrissey and Livingston, 1992].

A major uncertainty in the estimation of the northern wetland source of $\mathrm{CH}_{4}$, however, comes from the complete lack of flux

Copyright 1994 by the American Geophysical Union.

Paper number 93JD02457.

0148-0227/94/93JD-02457\$05.00 measurements from the large, extensive, semicontinuous peatlands of the Hudson Bay lowland $\left(\approx 0.32 \times 10^{6} \mathrm{~km}^{2}\right.$ ) and the western Siberian lowland $\left(=0.54 \times 10^{6} \mathrm{~km}^{2}\right.$ ). These two peatlands alone comprise $30 \%$ of all wetlands north of $40^{\circ} \mathrm{N}$. In the global estimates of $\mathrm{CH}_{4}$ flux, it has been assumed that the flux from relatively small, isolated wetlands is representative of fluxes from the wetlands of these vast regions.

The evolution and present-day ecology of the wetlands of the Hudson Bay Lowland is considerably different from that of more isolated systems [National Wetlands Working Group, 1988]. The southern section of the Hudson Bay lowland possesses a great diversity of wetland types and is an area that is almost entirely covered by wetlands or lakes and rivers [Glooschenko et al., this issue]. Within this diversity, there is a pattern of landscape evolution that is related to the emergence of the lowland from the Tyrrell Sea and the Bay, over the past 8000 years. This emergence has resulted in the development of a complex pattern of wetland types, representing a succession from the youngest wetlands near the coast to the oldest in the interior [Mortsch, 1990; Riley, 1982].

Methane emission from wetlands is controlled by a number of variables, including the rates of methane production and consumption by the soil microbial community and the ability of the 
soil and plant system to transport methane to the atmosphere. In turn, these variables are affected by factors such as the wetland hydrological and thermal regime and components of ecosystem functioning, such as rates of plant production and substrate quality. As wetlands evolve through time, through vegetation change and succession, so may the patterns of methane emission change. Thus by examining the patterns of methane emission both within each of the wetland ecosystems and along the successional gradient, the influence of ecosystem dynamics on methane emissions can be established.

The objective of the research reported in this paper was to examine the intrawetland and interwetland spatial and temporal variability of $\mathrm{CH}_{4}$ flux from wetlands along a $100-\mathrm{km}$ transect of the southern section of the Hudson Bay lowland, Ontario, Canada. This transect was chosen as the study site of the Northern Wetlands Study (NOWES) because it represents $\mathbf{5 0 0 0}$ years of peatland evolution [Glooschenko et al., this issue]. In addition to determining the fluxes of $\mathrm{CH}_{4}$ and the seasonal pattern, environmental variables that relate to the fluxes, such as hydrological and thermal regimes and edaphic and ecological factors, were also examined. This study, among others [Hamilton et al., this issue; Holland, 1991; Klinger et al., this issue], provided the basis for the estimation of the Hudson Bay lowland as a source of atmospheric $\mathrm{CH}_{4}$ [Roulet et al., this issue].

\section{Field Locations}

\section{METHODS}

Five major ecosystems were sampled along a $100-\mathrm{km}$ transect from the emerging James Bay coastline near North Point to the interior, at five main locations (Figure 1). In this paper, location is used to indicate position along the North Point to Kinosheo Lake transect, while the term site indicates an ecologically distinct area. A wetland type, such as bog, fen, etc., is defined using the classification system of Riley [1982]. Individual sites may represent single wetland types, or several types may represent a gradient of units within one wetland type (Table 1). Sixteen wetland types were classified, and the areal extent calculated by Roulet et al. [this issue]. The relative importance of each type is presented in Table 2. The following major ecosystems were sampled:
Coastal marsh. Five sites were established at the coastal marsh location $\left(51^{\circ} 29^{\prime} \mathrm{N}, 80^{\circ} 28^{\prime} \mathrm{W}\right.$ ) near North Point, representing recently emerged salt marshes and supertidal meadow marshes and pools [Glooschenko, 1978; Glooschenko and Clarke, 1982]. Organic matter accumulation is shallow $(<0.2 \mathrm{~m})$ and vascular plant species diversity is high.

Coastal fen. The coastal fen location ( $\left.51^{\circ} 28^{\prime} \mathrm{N}, 80^{\circ} 37^{\prime} \mathrm{W}\right)$, approximately $15 \mathrm{~km}$ inland from the coast, represents an open graminoid fen. One site was located in a wet fen with a dense cover of sedges (mainly Scirpus caespitosus, Carex limosa, Carex chordorhizza and Carex livida), another on a small ridge or string covered by shrubs (mainly birch, Betula pumila), rising $15 \mathrm{~cm}$ above the sedge fen. Peat accumulation averages $0.7 \mathrm{~m}$ in ths ecosystem. Two sites were located in a series of shallow ponds. In the coastal fen, about $70 \%$ of the area is covered by wet sedge, about $20 \%$ by the ridges, about $5 \%$ by pools, and about $5 \%$ by open/treed lowshrub islands. This location represents approximately 1000 years since emergence [Klinger et al., this issue].

Tamarack fen. The tamarack fens, generally covering the area of emergence of the estuarine sediments of the Moose River, were sampled at the coastal fen location and at a location $1 \mathrm{~km}$ northwest of the town of Moosonee ( $51^{\circ} 18^{\prime} \mathrm{N}, 80^{\circ} 38^{\prime} \mathrm{W}$ ). In this ecosytem there is strong microtopography of hummocks and hollows, with a cover of larch (Larix laricina), black spruce (Picea mariana), alder (Alnus rugosa) and shrubs such as Labrador tea (Ledum groenlandicum), and birch (B. pumila) and mosses (Sphagnum spp.) in the hummocks and hollows. At the coastal fen location, two sites represented the hummocks and hollows and at the location near Moosonee, four sites represented $L$. laricina and $A$. rugosa hummocks and hollows. Peat accumulation is variable but averages $0.6 \mathrm{~m}$, with 1500 year since emergence.

Interior fen. This ecosystem, sampled at a location $27 \mathrm{~km}$ from the coast $\left(51^{\circ} 31^{\prime} \mathrm{N}, 80^{\circ} 27^{\prime} \mathrm{W}\right)$, represents the initial stage of the increasing diversity within the wetland landscape, with the formation of treed mounds, underlain by permafrost, wet fen areas dominated by sedges, shrubs and Sphagnum spp., as well as pools and ponds, occasionally containing palsa-type mounds. Seven sites were selected to represent a sequence from a treed mound through a sedge/shrub area to two pools and a small emergent palsa within one of the

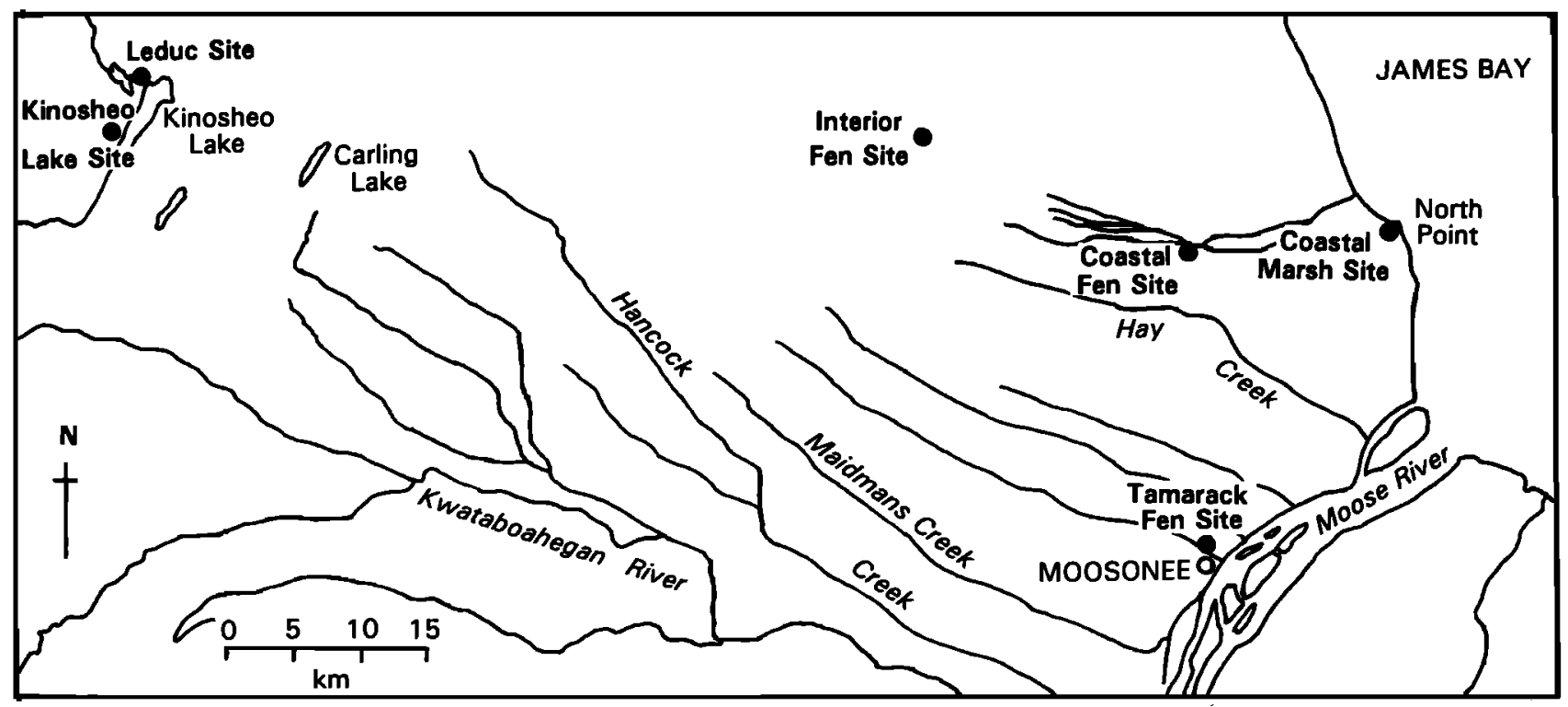

Fig. 1. The locations at which $\mathrm{CH}_{4}$ emission measurements were made in the southern part of the Hudson Bay lowland. 
TABLE 1. Ecological Types Represented by the 39 Sites Used for Methane Flux Measurements, Estimated Seasonal (June - October) $\mathrm{CH}_{4}$ Flux, Using Temporally Weighted Means and a 130-day Season, and Average Water Table Depth and Temperature at $20 \mathrm{~cm}$

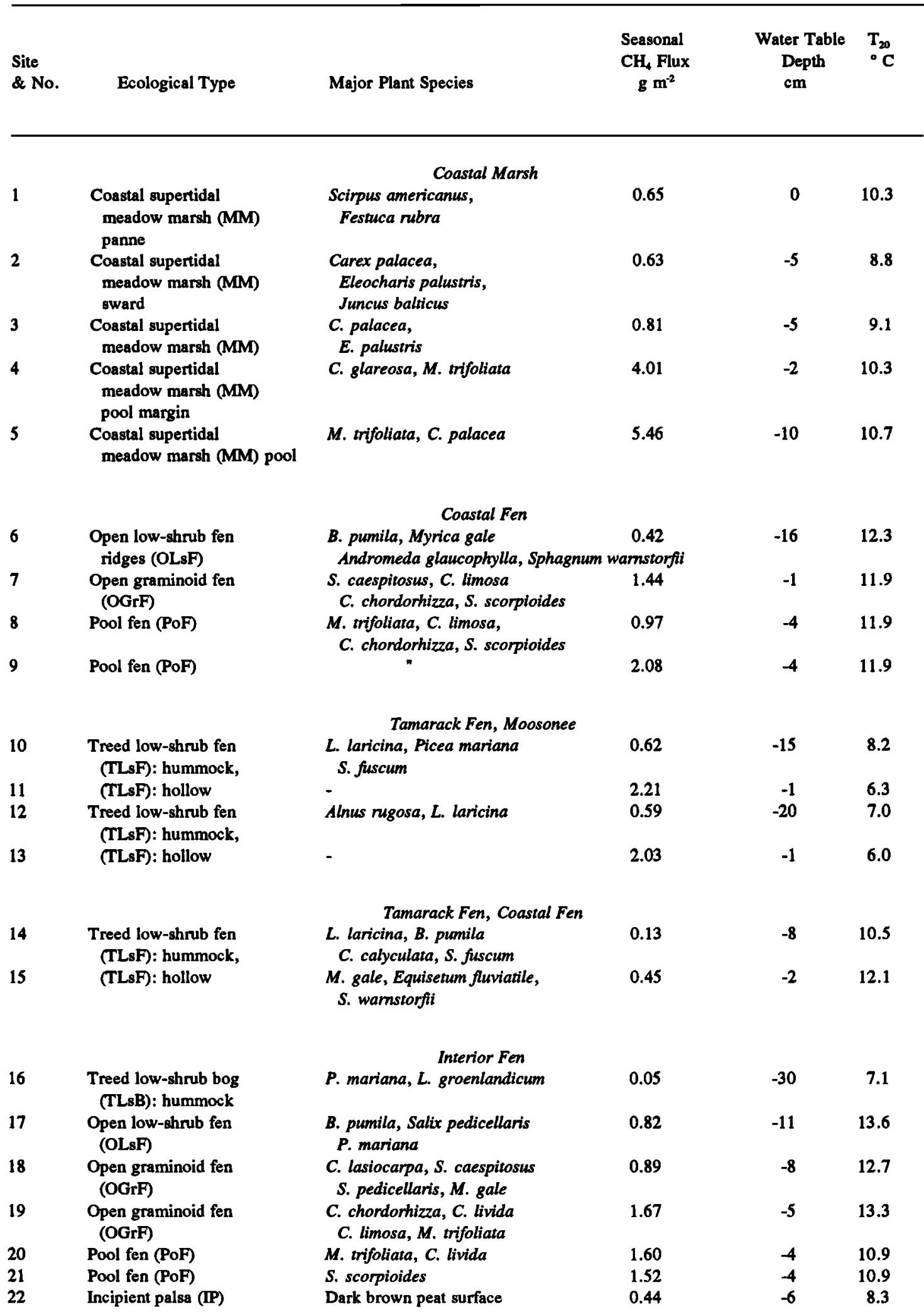




\begin{tabular}{|c|c|c|c|c|c|}
\hline $\begin{array}{l}\text { Site } \\
\& \text { No. }\end{array}$ & Ecological Type & Major Plant Species & $\begin{array}{l}\text { Seasonal } \\
\mathrm{CH}_{4} \text { Flux } \\
\mathrm{g} \mathrm{m}^{-2}\end{array}$ & $\begin{array}{l}\text { Water Table } \\
\text { Depth } \\
\text { cm }\end{array}$ & $\begin{array}{l}\mathbf{T}_{20} \\
{ }^{\circ} \mathbf{C}\end{array}$ \\
\hline & & Bog, Leduc & & & \\
\hline 23 & $\begin{array}{l}\text { Conifer feather } \\
\text {-moss forest }\end{array}$ & $\begin{array}{l}\text { P. mariana, L. groenlandicum, } \\
\text { Pleurozium schreberi }\end{array}$ & 0.33 & -20 & 9.5 \\
\hline 24 & $\begin{array}{l}\text { Open lichen-rich } \\
\text { low-shrub bog (OLrLsB) } \\
\text { : hummock }\end{array}$ & $\begin{array}{l}\text { C. calyculata, } S \text {. fuscum, } \\
\text { Cladina stygia }\end{array}$ & 0.46 & -21 & 10.6 \\
\hline 25 & : hollow & S. capillifolium, C. stellaris & 0.37 & -5 & 7.8 \\
\hline 26 & $\begin{array}{l}\text { Pool fen (PoF) \& open } \\
\text { graminoid bog (OGrB) of pools }\end{array}$ & S. scorpioides, S. hudsonianus & 3.26 & -8 & 11.4 \\
\hline 27 & $\begin{array}{l}\text { Pool fen (PoF) \& open } \\
\text { graminoid bog (OGrB) margin }\end{array}$ & $\begin{array}{l}\text { S. capillifolium, C. limosa } \\
\text { of pools }\end{array}$ & 1.79 & -16 & 12.7 \\
\hline 28 & Pool fen (PoF) \& margin & M. trifoliata, S. scorpioides & 4.81 & +3 & 12.5 \\
\hline 29 & Pool fen (PoF) & S. scorpioides & 4.11 & 0 & 9.4 \\
\hline 30 & Pool fen (PoF) & Black peat surface & 7.45 & +29 & 12.6 \\
\hline 31 & $\begin{array}{l}\text { Treed low-shrub } \\
\text { lichen-rich bog } \\
\text { (TLrLsB) }\end{array}$ & $\begin{array}{l}\text { Bog, Kinosheo Lake } \\
\text { P. mariana, L. groenlandicum } \\
\text { C. stellaris }\end{array}$ & 0.81 & -15 & 9.3 \\
\hline 32 & $\begin{array}{l}\text { Open lichen-rich, low- } \\
\text { shrub bog (OLrLsB) }\end{array}$ & C. calyculata, S. fuscum & 1.05 & -20 & 10.4 \\
\hline 33 & $\begin{array}{ll} & \text { : hummock } \\
& \text { : hollow }\end{array}$ & S. capillifolium, C. stellaris & 2.00 & -5 & 9.7 \\
\hline 34 & $\begin{array}{l}\text { Open pool fen margin } \\
\text { (PoF) }\end{array}$ & $\begin{array}{l}\text { Gymnocolea inflata, } \\
\text { Sphagnum lenense, Carex oligosperma }\end{array}$ & 16.61 & 0 & 12.1 \\
\hline 35 & $\begin{array}{l}\text { Open pool fen margin } \\
\text { (PoF) }\end{array}$ & S. scorpioides, $C$. oligosperma & 2.29 & 0 & 10.4 \\
\hline 36 & Deep pool & Peat bottom & 1.38 & +100 & 13.0 \\
\hline 37 & $\begin{array}{l}\text { Open sphagnum bog } \\
\text { (OSpB) }\end{array}$ & $\begin{array}{l}\text { S. capillifolium, } S \text {. tenellum, } \\
\text { C. oligosperma }\end{array}$ & 4.12 & -10 & 13.0 \\
\hline 38 & $\begin{array}{l}\text { Open graminoid bog } \\
\text { (OGrB) }\end{array}$ & $\begin{array}{l}\text { Scheuchzeria palustris, } \\
\text { C. oligosperma, S. capillifolium }\end{array}$ & 13.62 & +5 & 12.0 \\
\hline 39 & $\begin{array}{l}\text { Open graminoid bog } \\
\text { at pool edge }\end{array}$ & C. limosa, Kalmia polifolia & 7.13 & 0 & 12.8 \\
\hline
\end{tabular}

The site notation follows that of Riley [1982].

TABLE 2. Relative Coverage (\%) of Major Wetland Types of the North Point to Kinosheo Lake Transect As Determined by Landsat Thematic Mapper

\begin{tabular}{llrrrrr}
\hline Land Class & Site No. & Transect & $\begin{array}{r}0-30, \\
\mathbf{k m}\end{array}$ & $\begin{array}{r}31-60, \\
\mathbf{k m}\end{array}$ & $\begin{array}{r}61-90, \\
\mathbf{k m}\end{array}$ & $\begin{array}{r}91-120, \\
\mathbf{k m}\end{array}$ \\
\hline & & & & & & \\
Water & & 8.6 & 1.3 & 1.4 & 2.4 & 5.1 \\
Marsh & $1-5$ & 1.3 & 5.5 & 0.0 & 0.0 & 0.0 \\
Shrub fen & 6,16 & 22.5 & 26.3 & 21.6 & 20.9 & 19.2 \\
Open fen & $7,8,9,17,18$, & 18.0 & 16.7 & 27.1 & 17.5 & 12.1 \\
& $19,20,21,22,26$, & & & & & \\
Treed fen & $27,28,29,30$ & & & & & \\
Open bog & $10-15$ & 12.4 & 7.9 & 18.3 & 14.4 & 8.0 \\
$\begin{array}{l}\text { Treed bog } \\
\text { Conifer }\end{array}$ & $24,25,36-39$ & 13.4 & 0.3 & 8.6 & 16.9 & 26.6 \\
forest/swamp & $31,33,34$ & 14.7 & 2.4 & 12.7 & 22.2 & 20.2 \\
Other & 23 & 5.9 & 6.1 & 9.8 & 4.9 & 3.9 \\
& & 3.2 & 33.5 & 0.5 & 0.8 & 4.9 \\
\hline
\end{tabular}


pools. Peat accumulation varies from 0.8 to $1.9 \mathrm{~m}$ and represents about 2000 years since emergence.

Bog. This is the most diverse wetland landscape and was sampled near Kinosheo Lake, $114 \mathrm{~km}$ from the coast. The dominant wetland vegetation is open, lichen-rich, low-shrub bog, in which there is a strongly developed microtopography of hummocks and hollows. Mats of sedges and Sphagnum spp. surround pools with degrading floors of bare peat and brown moss ( $S$. scorpioides). Deeper ponds also occur, with an organic floor, and lakes commonly have a mineral floor. In better drained areas, feathermoss and mixed forests occur and these grade into treed low- shrub bogs dominated by $P$. mariana. Seventeen sites were sampled in the Kinosheo Lake area, eight at the Leduc location, $1 \mathrm{~km}$ northwest of the NOWES camp, and nine near the main NOWES tower location. Peat thicknesses are very variable, ranging from 1.0 to $3.5 \mathrm{~m}$ in the center of the raised bogs. Similarly, the average age of the peatland varies from the youngest at 2500 years to the oldest at 4100 years [Klinger et al., this issue].

Within each of these locations, there is a complex assemblage of wetland types, but the whole represents the ecological succession of wetlands from the coastal marsh to the interior bog [Riley, 1982](Figure 2). A total of 39 sites were sampled for methane emission measurements.

\section{Methane Emission Measurements}

Methane emissions at each site were made by a static chamber method. The chambers were made from polycarbonate $18-\mathrm{L}$ bottles (basal area $0.053 \mathrm{~m}^{2}$ ) from which the base had been removed. The neck of the chamber was sealed with a rubber stopper, containing a glass tube and rubber septum, through which air samples were collected with a $10-\mathrm{mL}$ syringe. The chambers were covered by aluminum foil to reduce heating. Chambers were gently inserted into the peat or down to the peat surface at flooded sites. At some of the larger pools the chambers were floated with styrofoam collars. Between two and five replicate chambers were employed at each site, with movement of the position of the chambers within the site. Studies of methane emission from subarctic fens has shown that methane concentrations inside the chamber increase linearly over 24 hours and that these static chambers generally underestimate flux compared to dynamic chambers, in which the air is circulated, by about $20 \%$, though there is a high spatial variability in emission rates within sites [Moore and Roulet, 1991].

The static chamber technique involves some disturbance of the surface layers of the peat during chamber insertion and prevents interaction of the ambient air with the peat surface. However, $\mathrm{CH}_{4}$ fluxes measured at the Kinosheo Lake location by static chambers compared well with areal estimates of flux derived from tower and aircraft measurements [Roulet, 1991]. Other studies have also found a good relationship between enclosures, tower and aircraft measurements [e.g., Bartlett et al., 1989a, 1992].

Air samples were extracted from the chamber when it was inserted and after an exposure period ranging from 2 to 3 hours, except for some overnight exposures during sampling in September and October. Methane concentrations were determined within 12 hours of collection (occasionally up to 48 hours) on a Shimadzu

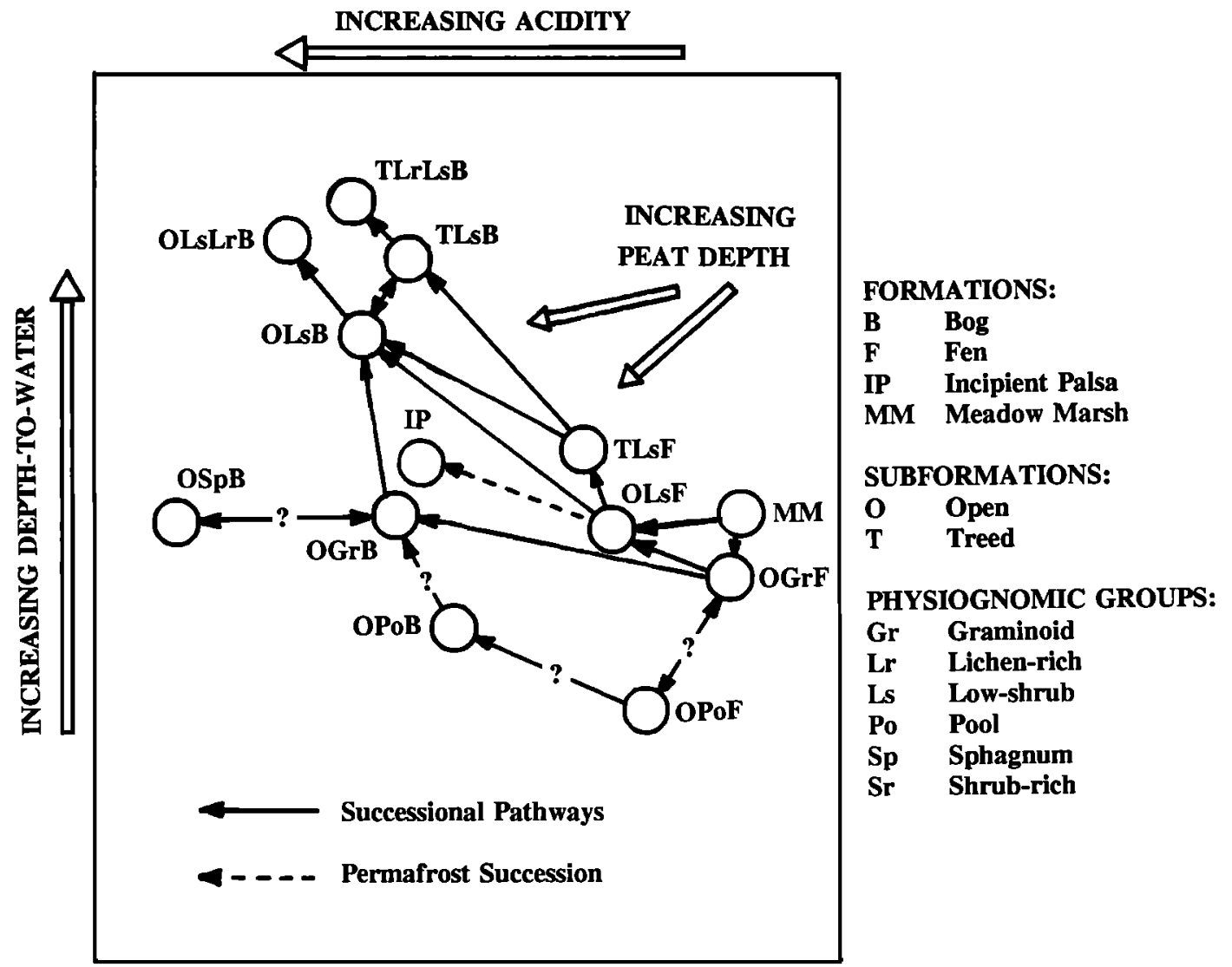

Fig. 2. The ecological succession pathways of the major wet types in the southern section of the Hudson Bay lowland [after Riley, 1982]. The ecological classification scheme is based on the plant species assemblage, including the formation and subformation and the physiognomic group. At the formation level, successional trends progress from meadow marsh through fen to bog and, dependent on climate, to palsa formations. These trends generally involve an increase in the peat depth, the depth-to-water and in peat acidity, though successional trends can be multidirectional at the level of physiognomic group. 
Mini 2 gas chromatograph, using a 5 - $\mathrm{mL}$ sample, a $1-\mathrm{mL}$ injection loop, and a Poropak- $Q$ column $(80 / 100$ mesh, $3 \mathrm{~m} \mathrm{x} 3 \mathrm{~mm})$ at $40^{\circ} \mathrm{C}$. Helium was used as the carrier gas at a flow rate of $30 \mathrm{~mL}$ $\mathrm{min}^{-1}$. No detectable leakage occurred in samples stored for up to 24 hours. Methane standards of nominally 2 and 200 parts per million by volume (ppmv) were used at the beginning of each analysis run. Methane fluxes were calculated from the change in the initial and final sample concentrations, corrected for the volume of air in the chamber and the exposure period. When the initial methane concentration exceeded $3 \mathrm{ppmv}$, the chamber was rejected, amounting to approximately $10 \%$ of the chamber measurements. Using the analytical error of the gas chromatograph ( $\pm 0.5 \mathrm{ppmv}$ ) and the volume and exposure period, the minimal detectable flux was $0.5 \mathrm{mg} \mathrm{CH}_{4} \mathrm{~m}^{-2} \mathrm{~d}^{-1}$.

Measurements of methane flux were made at $\approx 10$-day intervals from early June to mid-August and once in late September and midOctober. At most sites, the position of the water table was recorded in boreholes and the temperature of the peat profile was measured down to $100 \mathrm{~cm}$ with a thermistor probe.

During late September, 250 to $500-\mathrm{mL}$ samples of the 0 to $10-$ and 10 to $20-\mathrm{cm}$ depths of the peat profile were collected from selected sites, for laboratory incubations to determine the rates of methane production and consumption. Samples were stored at $4^{\circ} \mathrm{C}$ at moisture contents near to that at which they were collected: where samples were collected from beneath the water table, the collection bottle was filled with peat water. Methane production under anaerobic conditions was determined by placing $5 \mathrm{~g}$ of wet peat into triplicate $50-\mathrm{mL}$ Erlenmeyer flasks, evacuating the air under vacuum, backfilling with nitrogen and incubating at $15^{\circ} \mathrm{C}$. Concentrations of methane in the flask were determined on samples taken by a syringe through a Subaseal in the flask mouth and the methane production over 5 days was calculated. Methane consumption rates were determined by placing $5 \mathrm{~g}$ of wet peat into 50-mL Erlenmeyer flasks, adding methane to produce an initial concentration of $1000 \mathrm{ppm}$ in the flask and then incubating at $15^{\circ} \mathrm{C}$ under continuous shaking to avoid the development of anaerobic pockets in the peat. The methane consumption rate was calculated from the average decrease in methane concentration in the flask over a 5-day period.

\section{RESUlTS AND DISCUSSION}

\section{Climatic Context}

It has been documented that there can be significant year-to-year variations in $\mathrm{CH}_{4}$ flux from northern wetlands, associated with differences in temperature, precipitation, and resultant water table position [e.g., Dise, 1992; Holland, 1991; Moore and Knowles, 1990; Whalen and Reeburgh, 1988; 1992]. As reported by Mortsch [this issue], the 1990 climate at Moosonee was characterized by mean daily temperatures of $11.5,16.9,14.5,7.9$, and $3.0^{\circ} \mathrm{C}$ for June, July, August, September, and October, respectively. With the exception of July (which was 1.6 $\mathrm{C}$ warmer than the 1951-1980 average) these values are all within one standard deviation of the 1951-1980 average.

Mean monthly precipitation in 1990 was $163,67,88,100$, and $61 \mathrm{~mm}$ in the June to October months, representing 207,69,110, 124 , and $82 \%$ of the 1951-1980 mean value. June was about twice as wet as normal, mainly because of the $64 \mathrm{~mm}$ of precipitation which fell on June 3, 1990, before the chamber measurements were started. Thus compared to an average year, the Moosonee section of the lowland received average temperatures and a much wetter than average June and drier than average July, with the other months being close to the normal. Based on year-to-year variations in $\mathrm{CH}_{4}$ flux from other northern wetlands [e.g., Moore and Knowles, 1990; Whalen and Reeburgh, 1992], the fluxes measured from the Hudson Bay lowland sites in 1990 may be larger than normal.

\section{Spatial Variability of Methane Emissions Within Sites}

As has been observed before [e.g., Moore and Knowles, 1990; Moore and Roulet, 1991; Whalen and Reeburgh, 1988, 1992], within-site spatial variability in $\mathbf{C H}_{4}$ flux is high, with coefficients of variation (standard deviation/mean) within visually uniform sites commonly falling between $\mathbf{5 0}$ and $100 \%$. This means that estimates of average $\mathrm{CH}_{4}$ emissions from a site have a high statistical error associated with them. Within visually uniform sites, 30 to 40 chambers are required to attain a precision $<15 \%$, as illustrated by the change in the ratio of the standard error/mean for measurements at two subarctic fen sites near Schefferville, randomly selected and sequentially added (Figure 3). This pattern is similar to that which has been found in wetlands in the Everglades, Florida [Bartlett et al., 1989b]. Within each of the locations in the present study (comprising between six and nine sites), $\mathrm{CH}_{4}$ flux variability is high, so that, even with $\mathbf{4 0}$ chambers, the precision of the mean commonly falls between \pm 30 and $60 \%$ (Figure 3 ).

\section{Temporal Patterns of Methane Emission}

Visual examination of the seasonal pattern of $\mathrm{CH}_{4}$ emission from the 39 sites suggests that there are six types, which are illustrated by representative sites in Figure 4. (1) Three sites showed a pattern which alternates between small negative and positive fluxes of $\mathrm{CH}_{4}$. These sites are the relatively well-drained forested sites at the bog and interior fen locations (sites 16, 23, and 31 in Table 1). (2) six sites $(5,6,18,29,32$, and 38$)$ showed a summer peak emission of $\mathrm{CH}_{4}$, which may be associated with temperature as the major control. (3) eight sites $(7,8,9,17,19,20,24$, and 27$)$ showed a

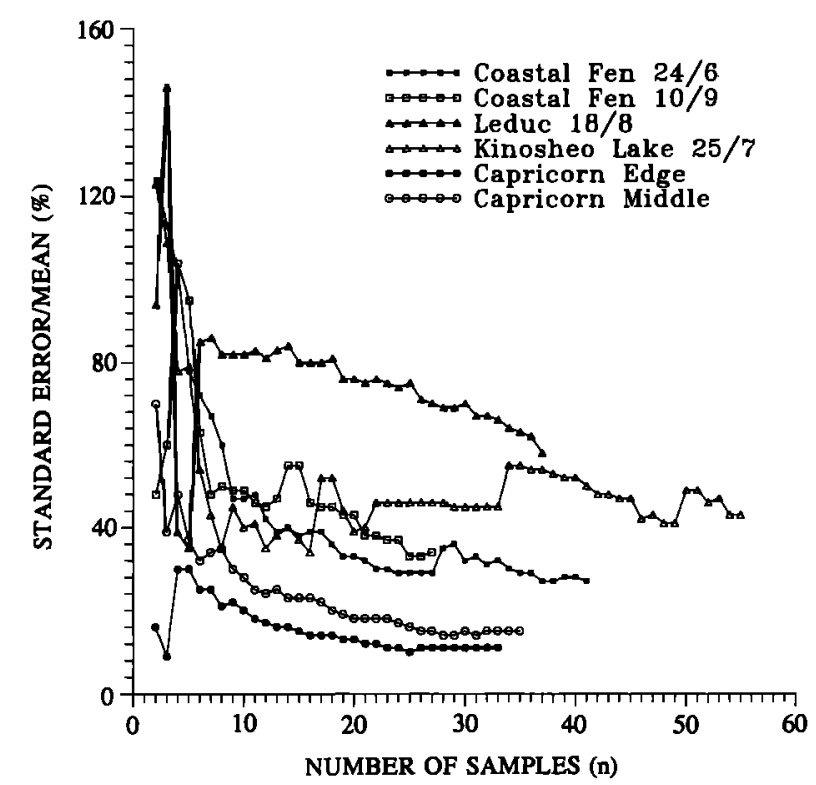

Fig. 3. Within-location variability in methane flux, for coastal fen, Leduc and Kinosheo locations, and within two visually uniform subarctic fens (Capricorn edge and middle) near Schefferville [from Moore and Roulet, 1990]. The ratios for the Hudson Bay lowland locations were generated by pooling all the data from the sites at that location, resulting in a sample size ranging from 28 to 58 . 

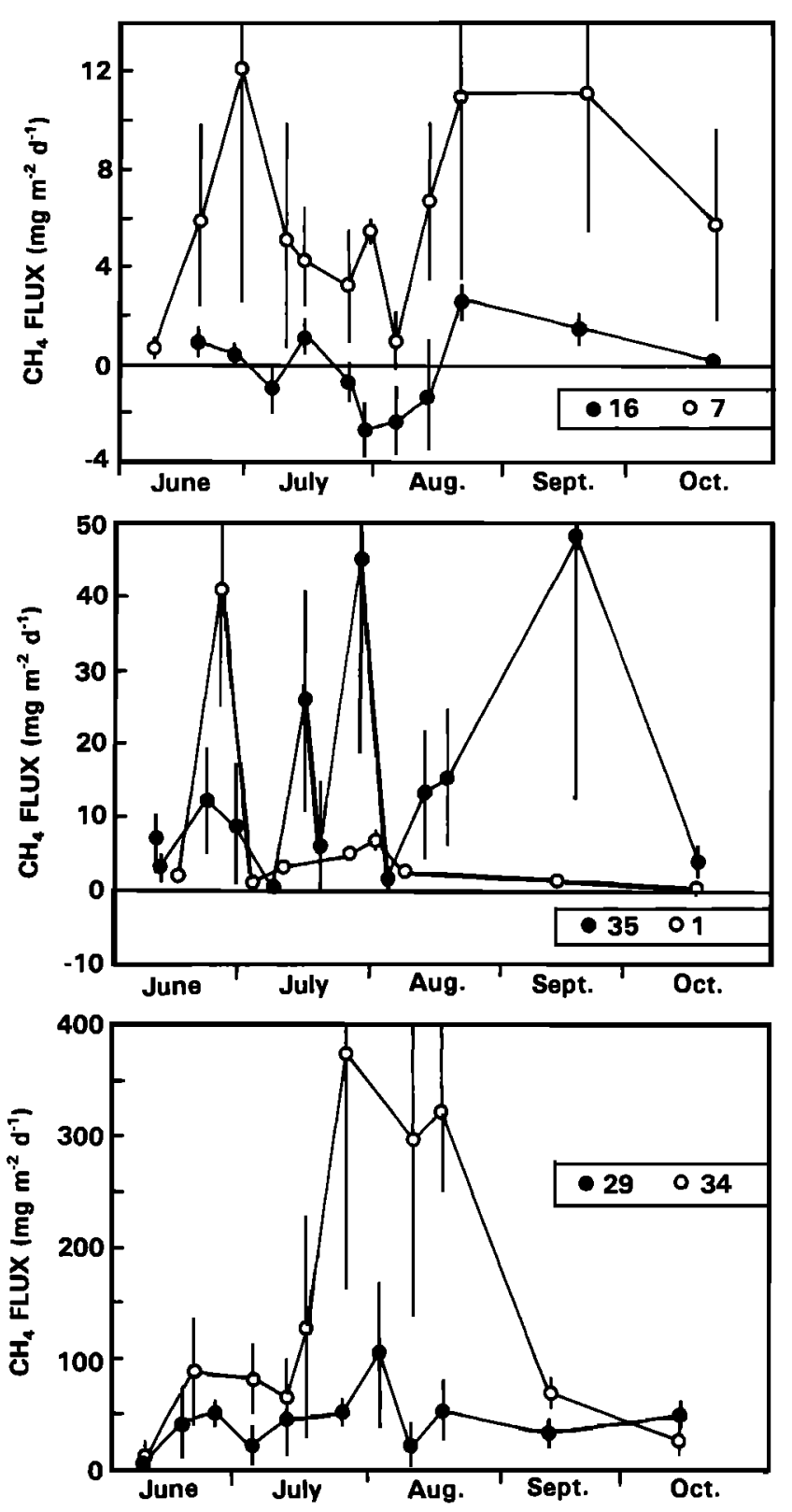

Fig. 4. The seasonal pattern of methane emission from selected sites: sites 7 (open graminoid fen, coastal fen) and 16 (treed low shrub bog hummock, interior fen); sites 29 (pool fen, Leduc bog) and 34 (open pool fen margin, Kinosheo Lake bog); sites 1 (meadow marsh, coastal marsh) and 35 (open pool fen margin, Kinsheo Lake bog). Vertical lines represent the standard deviation around the mean, based on replicate chamber measurements.

pattern of larger $\mathrm{CH}_{4}$ emissions in spring and early summer, a decrease during the summer and an increase in the fall. (4) six sites $(25,26,30,33,34$, and 37$)$ showed a gradual increase toward late summer and fall, when the sites were both warm and waterlogged. (5) four sites $\left(1,3,28\right.$ and 36) showed a decrease in $\mathrm{CH}_{4}$ emissions from spring to fall.(6) six sites showed no discernible pattern (sites $2,14,15,21,22$ and 35).

The change in $\mathrm{CH}_{4}$ flux over the study period is the result of a series of covarying processes that are impossible to assess individually. While there is no direct evidence of which factors are dominant at a particular site, there is sufficient knowledge of the controls on the production, oxidation, and transport of $\mathrm{CH}_{4}$ to conjecture about the possible source of these patterns. In pattern 1 , small fluxes, both emission and uptake, were dominated by a thick unsaturated layer with a high potential for oxidation. Sites where increasing fluxes (pattern 4) or summer peak flux (pattern 2) had little capacity to oxidize the produced $\mathrm{CH}_{4}$ because of a high level of saturation; therefore the seasonal pattern of temperature was important. Sites that experienced a mid-summer decrease in flux (pattern 3) had a high potential for oxidation because a thick unsaturated zone had developed with a drop in the water table. A large spring flux followed by small fluxes (pattern 5) may be caused by the release of stored $\mathrm{CH}_{4}$, trapped beneath the ice cover.

From the seasonal pattern of $\mathrm{CH}_{4}$ emissions, an estimate was made of the seasonal flux from each of the sites, by taking the temporally integrated mean value and applying a season length of 130 days. This is likely to be an underestimate of the annual flux of $\mathrm{CH}_{4}$ from the wetland sites, for a number of reasons. Short-duration, episodic fluxes of $\mathrm{CH}_{4}$ have been noted from several northem fens, associated with the buildup of pore-water $\mathrm{CH}_{4}$ concentrations and small falls in the position of the water table [e.g., Moore et al., 1990; Windsor et al., 1992]. These episodic events are unlikely to have been caught by the weekly sampling scheme employed in the Hudson Bay lowland, and may result in an underestimate of the seasonal $\mathrm{CH}_{4}$ flux [Windsor et al., 1992]. Secondly, it has been shown that there can be significant emissions of $\mathrm{CH}_{4}$ during the winter and during the spring thaw, as $\mathrm{CH}_{4}$ trapped within and beneath the ice is released [e.g., Dise, 1992; Moore and Knowles, 1990; Moore et al., 1990; Whalen and Reeburgh, 1988, 1992]. In addition, the absence of wind movement within the static chambers results in a lower flux than if the air was circulated at speeds similar to that outside the chamber [e.g., Moore and Roulet, 1991; Sebacher et al., 1983]. The combination of these phenomena mean that the seasonal flux estimate may underestimate the annual flux by $20 \%$.

At the coastal marsh location, recently emerged from the Bay, seasonal $\mathrm{CH}_{4}$ emission rates were low at the three raised sites underlain by primarily inorganic sediment, even though the water table was high, with fluxes estimated to range from 0.6 to $0.8 \mathrm{~g} \mathrm{~m}^{-2}$ (Table 1). Emission rates were much larger at two small pool sites, with a vegetation of sedges and buckbean and water $0-10 \mathrm{~cm}$ above the organic sediment surface, amounting to seasonal emissions of 4.0 and $5.5 \mathrm{~g} \mathrm{~m}^{-2}$.

At the coastal fen location the shrub-covered ridges were raised about $15 \mathrm{~cm}$ above the water table and showed small $\mathrm{CH}_{4}$ fluxes, resulting in a seasonal emission of $0.4 \mathrm{~g} \mathrm{~m}^{-2}$ (Table 1). The lowerlying, sedge-covered sections had a water table close to the peat surface for most of the time (average water depth $3 \mathrm{~cm}$ ) and a seasonal $\mathrm{CH}_{4}$ flux of $1.4 \mathrm{~g} \mathrm{~m}^{-2}$. The shallow pools within the coastal fen also showed small $\mathrm{CH}_{4}$ fluxes, 1.0 to $2.1 \mathrm{~g} \mathrm{~m}^{-2}$.

At the two tamarack fen locations the hummocks, located 10 to $20 \mathrm{~cm}$ above the water table and containing ice for much of the summer, exhibited small $\mathrm{CH}_{4}$ fluxes with seasonal $\mathrm{CH}_{4}$ emissions of 0.1 to $0.6 \mathrm{~g} \mathrm{~m}^{-2}$ (Table 1). The adjacent hollows, where the water table was always close to the peat surface, showed larger $\mathrm{CH}_{4}$ fluxes, with seasonal emissions of 0.5 to $2.2 \mathrm{~g} \mathrm{~m}^{-2}$.

At the interior fen location the raised hummock, covered by trees and mosses and with a permafrost core, exhibited very low rates of $\mathrm{CH}_{4}$ emission and occasional $\mathrm{CH}_{4}$ uptake, resulting in a very small seasonal $\mathrm{CH}_{4}$ flux of $0.1 \mathrm{~g} \mathrm{~m}^{-2}$ (Table 1). Along a hydrological gradient from a dominantly shrub-covered upper site to a lower site adjacent to a pool and vegetated with sedges and buckbean, $\mathrm{CH}_{4}$ emission rates increased with seasonal fluxes of 0.8 to $1.7 \mathrm{~g} \mathrm{~m}^{-2}$. Two pool sites sampled emitted $1.5-1.6 \mathrm{~g} \mathrm{CH}_{4} \mathrm{~m}^{-2}$ and an incipient palsa emerging from one of the pools, with a bare peat surface about $20 \mathrm{~cm}$ above the water surface, emitted $0.4 \mathrm{~g} \mathrm{CH}_{4} \mathrm{~m}^{-2}$.

The two bog locations showed the greatest within-location 
variations in $\mathrm{CH}_{4}$ flux. The two forest sites emitted small amounts of $\mathrm{CH}_{4}\left(0.3\right.$ and $\left.0.8 \mathrm{~g} \mathrm{~m}^{-2}\right)$, as did the hummocks covered with mixtures of shrubs, lichens, and mosses $\left(0.5\right.$ to $1.0 \mathrm{~g} \mathrm{~m}^{-2}$,) and both sets of sites had water tables lower than 15 to $20 \mathrm{~cm}$ beneath the peat surface (Table 1). The hollows adjacent to the hummocks also emitted small amounts of $\mathrm{CH}_{4}, 0.4$ to $2.0 \mathrm{~g} \mathrm{~m}^{-2}$, even though the water table was closer to the hollow peat surface for much of the summer. The sites at the Leduc location generally emitted smaller amounts of $\mathrm{CH}_{4}$ than their equivalents at the Kinosheo lake location, probably because of the drier, more raised nature of the former. In the graminoid and moss fen and bog sections of the locations, $\mathrm{CH}_{4}$ emissions were greater, especially on the margin of pools, from moss mats and in sections where the peat appeared to be degrading to form incipient pools. Seasonal fluxes of $\mathrm{CH}_{4}$ from these ecological types ranged from 1.8 to $16.6 \mathrm{~g} \mathrm{~m}^{-2}$ with an average of $6.4 \mathrm{~g} \mathrm{~m}^{-2}$ and the water table was always close to the peat surface. Seasonal $\mathrm{CH}_{4}$ flux from the pool site at the Leduc location was also high, $7.5 \mathrm{~g} \mathrm{~m}^{-2}$, but the flux from the deeper pool at Kinosheo Lake, sampled with floating chambers, was lower, $1.4 \mathrm{~g} \mathrm{~m}^{-2}$.

Roulet et al. [this issue] determined the spatially weighted mean $\mathrm{CH}_{4}$ flux from the five ecosystems, using the fluxes described in this paper and those from Hamilton et al. [this issue] and Klinger et al. [this issue], and the areal coverage of vegetation units derived from color air photography. In order of lowest to highest seasonal emission rates of $\mathrm{CH}_{4}$, they are: treed bog $0.18 \mathrm{~g} \mathrm{~m}^{-2}$, treed (tamarack) fen $0.38 \mathrm{~g} \mathrm{~m}^{-2}$, marsh $2.30 \mathrm{~g} \mathrm{~m}^{-2}$, open fen $2.78 \mathrm{~g} \mathrm{~m}^{-2}$, and open bog $4.60 \mathrm{~g} \mathrm{~m}^{-2}$.

\section{Controls on Methane Emissions}

Temperature and water table. There were a few very weak statistical correlations between daily $\mathrm{CH}_{4}$ emissions at the sites and the position of the water table and the temperature at depths of 10 and $20 \mathrm{~cm}$. Most relationships were insignificant at the $p<0.05$ level between the daily $\mathrm{CH}_{4}$ flux (and $\log \mathrm{CH}_{4}$ flux) and these three variables. Multiple regressions between daily $\mathrm{CH}_{4}$ flux (and $\log \mathrm{CH}_{4}$ flux) and water table and temperature also failed to produce many significant correlations, so that these variables are of little use as predictors of $\mathrm{CH}_{4}$ emission within sites.

Weak statistical associations of this nature have been reported from other northern wetlands [e.g., Moore et al., 1990; Whalen and Reeburgh, 1988; 1992], though other studies have been able to identify stronger relationships between these variables and $\mathrm{CH}_{4}$ emissions [e.g., Crill et al., 1988; Dise, 1992; Harriss et al., 1992]. Part of the explanation for the weak association lies in the high spatial variability recorded for $\mathrm{CH}_{4}$ emissions at each sampling date within the site (coefficients of variation of 50 to $100 \%$ ). Sampling the same chamber location within a site will reduce the date-to-date sampling variability. In addition, there are short-term emissions of $\mathrm{CH}_{4}$ associated with small drops in the position of the water table, or through the release of $\mathrm{CH}_{4}$ trapped beneath or within melting ice [e.g., Windsor et al., 1992], as well as a timelag between changes in temperature and water table position and the microbial response of $\mathrm{CH}_{4}$ production and consumption. Furthermore, the temperature responses of $\mathrm{CH}_{4}$ production and oxidation are different [Dunfield et al., 1993]. Whalen and Reeburgh [1992] note that single environmental variables may be of limited value in predicting variations in $\mathrm{CH}_{4}$ flux and that variables which are environmental integrators are more successful.

Although there were poor statistical relationships between $\mathrm{CH}_{4}$ emission rates and temperature and water table at sites during the sampling season, these two variables were strongly correlated with the seasonal flux of $\mathrm{CH}_{4}$ from the sites. There was a significant correlation $\left(r^{2}=0.44, p<0.001\right)$ between the logarithm of the seasonal $\mathrm{CH}_{4}$ flux at the sites and the mean depth to the water table, when the outlier deep pond site at Kinosheo Lake was excluded (Figure 5). The relationship between seasonal $\mathrm{CH}_{4}$ flux and mean temperature at a depth of either 10 or $20 \mathrm{~cm}$ was weaker but still significant $\left(r^{2}=0.13\right.$ and $0.15, p=0.024$ and 0.016 , respectively, Figure 5). Combination of the water table and temperature variable $\left(T_{20}\right)$ into a step-wise regression accounted for $48 \%$ of the variation in the logarithm of the seasonal $\mathrm{CH}_{4}$ flux, with the $\mathrm{T}_{20}$ contribution insignificant. In this range of peatland types there is an insignificant relationship between seasonal mean water table position and mean temperature at 10 or $20 \mathrm{~cm}\left(r^{2}=0.04\right.$ to 0.08$)$, probably because of the great diversity in peat physical characteristics, which control the movement of energy into and out of the peat profile.

These overall relationships emphasize the importance of the hydrologic regime, especially the position of the water table, in controlling overall $\mathrm{CH}_{4}$ emissions from northem wetlands. In the Alaskan tundra, Bartlett et al. [1992], Morrissey and Livingston [1992], and Whalen and Reeburgh [1988, 1992] have noted the importance of hydrology in controlling $\mathrm{CH}_{4}$ emission rates. A similar relationship, with water table position assuming greater significance than temperature, has been obtained for the low boreal wetlands of southern Ontario by Roulet et al. [1992]. Moore and Roulet [1993] have also shown that this regional relationship between seasonal $\mathrm{CH}_{4}$ emissions and water table position is characterized by regressions with a similar slope yet a different constant.

The cold thermal regime of these northern peatlands may play an overall role in the small $\mathrm{CH}_{4}$ emission rates. Although the surface of the peat can become warm during the summer $\left(>20^{\circ} \mathrm{C}\right.$ ), there are strong thermal gradients down from the surface, especially at the drier sites, so that beneath $20 \mathrm{~cm}$, the peat remains cool $\left(<10^{\circ} \mathrm{C}\right)$, as has been found in other subarctic fens [e.g., Moore, 1987]. Using peat samples from the coastal fen and Kinosheo Lake sites, Dunfield et al. [1993] showed in laboratory incubations that methanogenesis was weak at $<10^{\circ} \mathrm{C}$, there was an absence of psychrophilic methanogenesis, and that the temperature dependence of methanogenesis was strong, with $Q_{10}$ values between 3 and 7 . In contrast, $\mathrm{CH}_{4}$ consumption rates showed a weaker temperature dependence, with $Q_{10}$ values falling between 1 and 2 . Thus at low temperatures $\left(5^{\circ}-10^{\circ} \mathrm{C}\right), \mathrm{CH}_{4}$ production is slow and $\mathrm{CH}_{4}$ consumption is fast, compared to rates at higher temperatures.

Edaphic Factors. Although water table and temperature provide some explanation for the variations in $\mathrm{CH}_{4}$ flux from the wetland sites, there is still considerable unexplained variability. As noted in the introduction, the ability of the soil to support $\mathrm{CH}_{4}$ production and consumption may be an important control. To evaluate the range in abilities of the peats to produce and consume $\mathrm{CH}_{4}$, we incubated samples of the 0 to 10 - and 10 to $20-\mathrm{cm}$ layers of the profile under laboratory conditions of $15^{\circ} \mathrm{C}$ and anaerobic and aerobic atmospheres, respectively. Previous work with laboratory incubations has revealed that the largest rates of $\mathrm{CH}_{4}$ production and consumption generally occur in the surface layers [Moore and Knowles, 1990], and the surface layers also attain the highest summer temperatures. Using samples collected in September and kept cool, the ability of the peat sample to produce and consume $\mathrm{CH}_{4}$ reflects the populations of methanogens and methanotrophs at the the time of collection and changes during storage, as well as the substrate characteristics of the sample that promote methane production and oxidation. There may be seasonal variations in the $\mathrm{CH}_{4}$ production rate of the peat, as observed by Yavitt et al. [1987] in a temperate peatland.

The results of the laboratory incubations illustrate the wide range of production and consumption rates found in the peat samples, 


$$
\log \mathrm{CH}_{4}=0.031 \mathrm{WT}+0053 \mathrm{~T}_{20}-1.753\left[\mathrm{r}^{2}=0.483\right]
$$
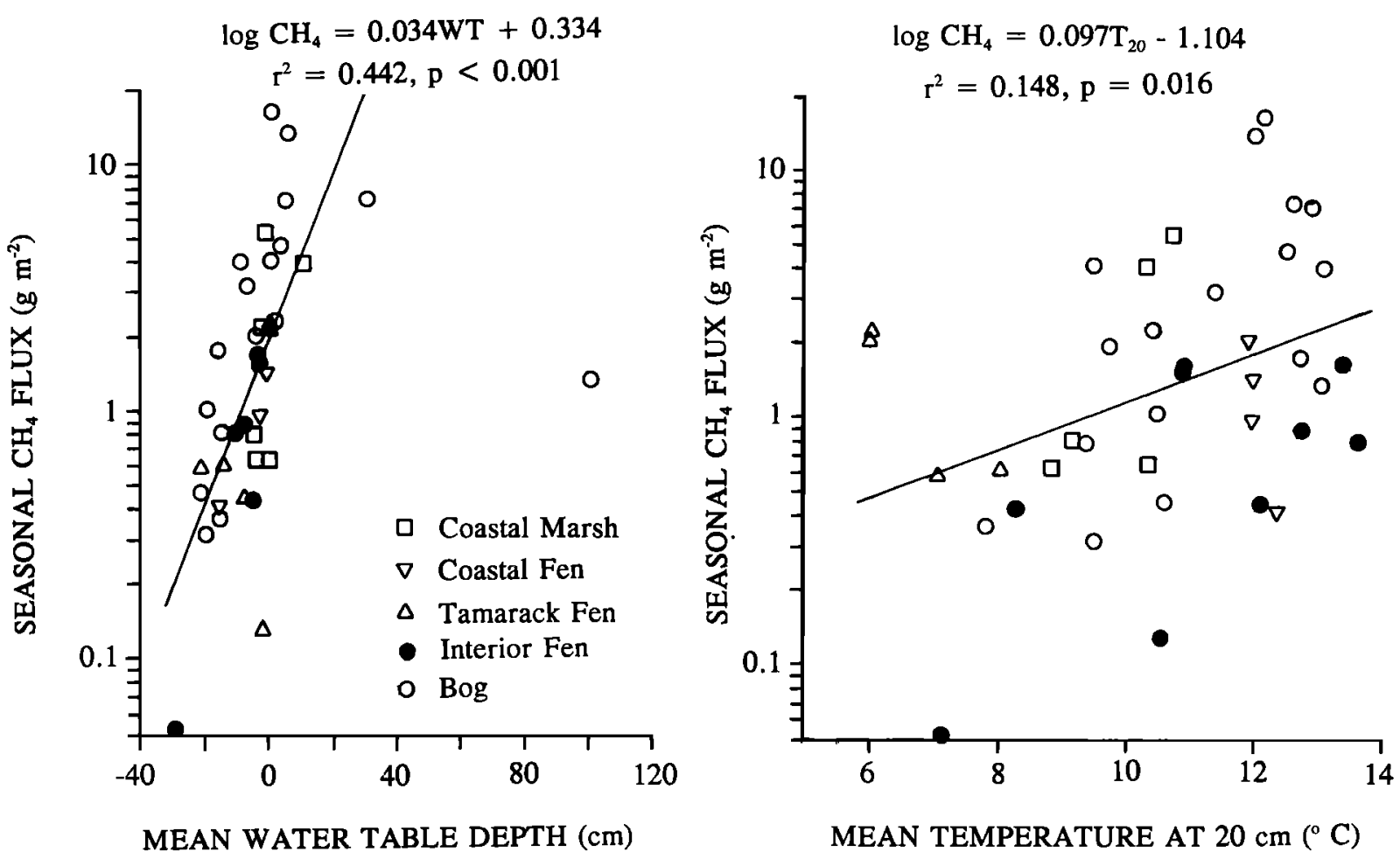

Fig. 5. Relationship between seasonal methane flux and mean water table position and temperature at $20 \mathrm{~cm}$ from all the sites in the Moosonee area. For the water table relationship, the outlier, representing a deep pond, has been excluded from the regression depicted.

covering 3 orders of magnitude (Figure 6). Although the absolute values are of little importance, aerobic $\mathrm{CH}_{4}$ consumption rates ranged from 0.1 to $50 \mu \mathrm{g} \mathrm{g}^{-1}$ peat d $\mathrm{d}^{-1}$ and anaerobic $\mathrm{CH}_{4}$ production rates ranged from 0.02 to $8 \mu \mathrm{g} \mathrm{g}^{-1} \mathrm{~d}^{-1}$. In all cases, consumption rates exceeded production rates, though this is a function of the laboratory conditions in which aerobic consumption was measured as the decrease in $\mathrm{CH}_{4}$ from an initial concentration of $1000 \mathrm{ppmv}$.

The 30 peat samples analyzed generally fall into three main types. Some samples had very low production and consumption rates ( $<0.1$ and $5 \mu \mathrm{g} \mathrm{g}^{-1} \mathrm{~d}^{-1}$, respectively). These mainly include the samples collected from the hummocks at the interior fen and bog, which are located well above the water table and which had very low $\mathrm{CH}_{4}$ fluxes and, in some cases, occasionally exhibited $\mathrm{CH}_{4}$ consumption in the field. The majority of the samples fell into the second group, characterized by low rates of $\mathrm{CH}_{4}$ production $(<0.5$ $\left.\mu \mathrm{g} \mathrm{g}^{-1} \mathrm{~d}^{-1}\right)$ and moderate to high rates of aerobic $\mathrm{CH}_{4}$ consumption $\left(5\right.$ to $\left.20 \mu \mathrm{g} \mathrm{g}^{-1} \mathrm{~d}^{-1}\right)$. These include sites with a wide range of field $\mathrm{CH}_{4}$ flux, and both 0 to 10 - and 10 to $20-\mathrm{cm}$ depth increments. The third group consisted of a small number of samples, mainly from the 10- to the 20-cm depth, which exhibited high rates of both $\mathrm{CH}_{4}$ production and consumption. None of the peat samples showed high rates of $\mathrm{CH}_{4}$ production and low rates of $\mathrm{CH}_{4}$ consumption. A high aerobic $\mathrm{CH}_{4}$ consumption rate is coupled with a high anaerobic $\mathrm{CH}_{4}$ production rate.

The incubation results help to explain some of the field flux patterns. For example, despite the high water table and the dense sedge cover, possibly leading to plant-mediated $\mathrm{CH}_{4}$ emission [Whiting and Chanton, 1992], field emissions of $\mathrm{CH}_{4}$ from the graminoid fen at the coastal fen location are small $\left(1.4 \mathrm{~g} \mathrm{~m}^{-2}\right.$ over the season). The incubation results reveal that the subsurface sample (10 to 20-cm) had the highest rates of $\mathrm{CH}_{4}$ production and consumption observed (Figure 7$)$. However, the surface sample (0 to $10-\mathrm{cm}$ ) exhibited low rates of $\mathrm{CH}_{4}$ production and very large rates of $\mathrm{CH}_{4}$ consumption in laboratory incubations, suggesting that the surface layer of the peat oxidizes much of the $\mathrm{CH}_{4}$ before it can be emitted to the atmosphere. The conditions which produce a high $\mathrm{CH}_{4}$ consumption capacity in the surface layer of the coastal fen site are unknown but may be related to high rates of oxygen production by algae at sites where the water table is at or close to the peat surface [King, 1990]. As noted by King et al. [1990] in wetlands of the Florida Everglades and Whalen et al. [1993] in Alaskan tundra, the capacity of the upper part of the soil profile to oxidize $\mathrm{CH}_{4}$ plays an important role in determining the emission of $\mathrm{CH}_{4}$ to the atmosphere: 50 to $90 \%$ of the $\mathrm{CH}_{4}$ produced in the profile may be oxidized.

On the other hand, the incubation results suggest that controls on $\mathrm{CH}_{4}$ flux at other sites may lie beneath the surface layers of the peat. The highest seasonal $\mathrm{CH}_{4}$ fluxes $\left(4\right.$ to $17 \mathrm{~g} \mathrm{~m}^{-2}$ ) were observed at the degrading pool peat sections at the Kinosheo Lake and Leduc bog locations. The incubation experiment, however, showed that both the 0 to 10 - and the 10 to 20 -cm samples from these sites exhibited small rates of $\mathrm{CH}_{4}$ production and large rates of $\mathrm{CH}_{4}$ consumption, suggesting that the main source of $\mathrm{CH}_{4}$ emitted from these sites was produced deeper in the peat profile.

Along the transect there were major changes in peat and porewater chemistry, reflecting the changes in nutrient availability and removal of salt during the ecological succession (Figure 2). Successional trends involve an increasing depth of peat, an increasing depth to water table and creation of pools, and a decreasing soil pH [Riley, 1982]. The soils at the coastal marsh, coastal fen, and tamarack fen locations are circumneutral to slightly acid in the upper $20 \mathrm{~cm}$, and the soil $\mathrm{pH}$ decreases at the sites in the interior fen and bog locations, falling to acid values ( $\mathrm{pH} 3.1$ - 5.2) in the upper layers of the peat (Table 3). This decrease in soil $\mathrm{pH}$ 


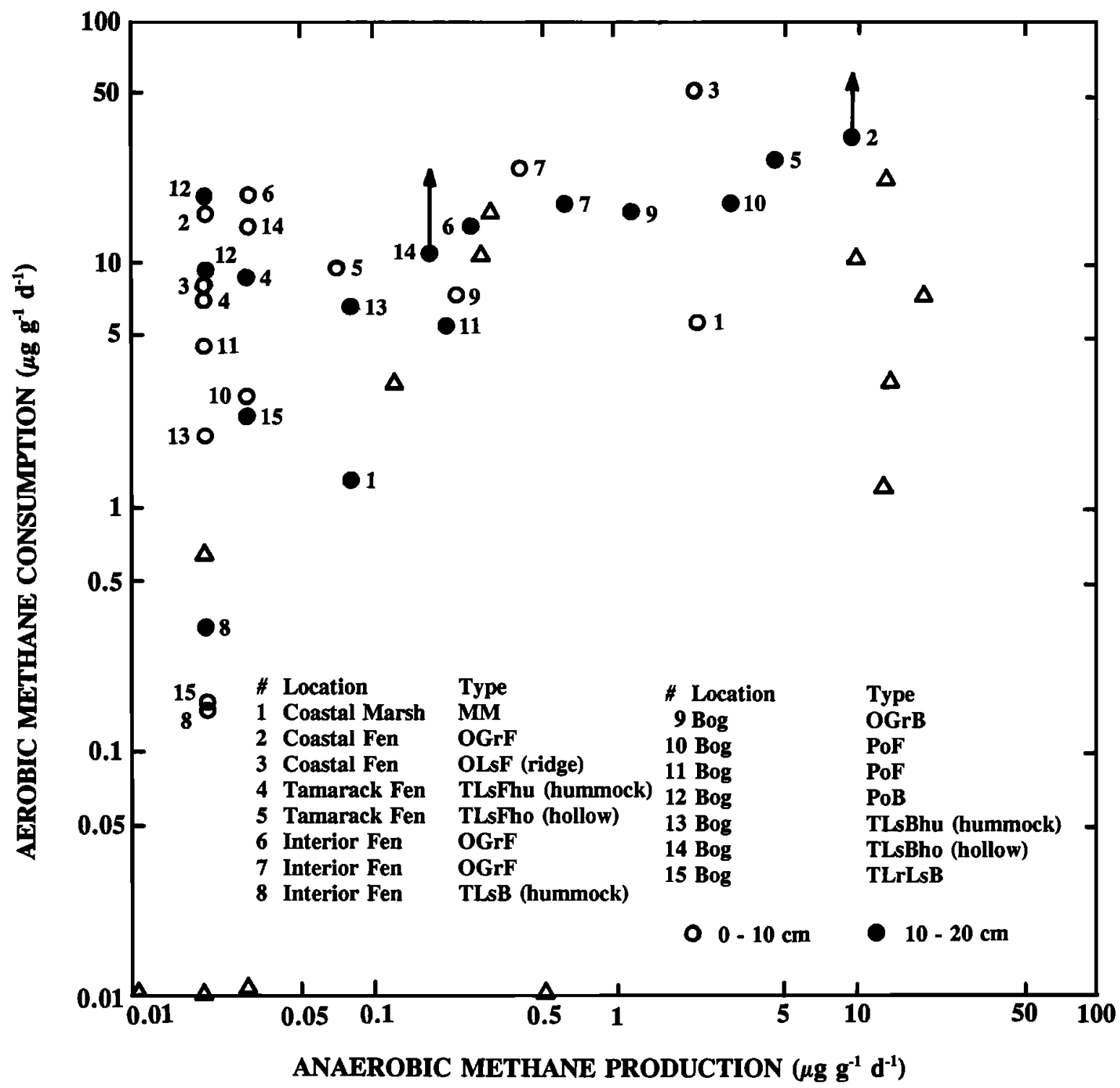

Fig. 6. Rates of methane production under anaerobic conditions and methane consumption under aerobic conditions, for the 0 to $10-\mathrm{cm}$ and 10 to $20-\mathrm{cm}$ samples collected from selected sites in the southern Hudson Bay Lowland. Also included are values (triangles) from 0 to $25-\mathrm{cm}$ depth samples from wetlands in the Churchill area in the northern section of the Lowland [Holland, 1991]. Each point is the mean of triplicate incubations. Arrows indicate that the value used for aerobic $\mathrm{CH}_{4}$ consumption is a minimum one, because of the fast consumption rate in the flask.

is matched by the decrease in specific conductance and cation $\left(\mathrm{Ca}^{2+}\right.$, $\mathrm{Mg}^{2+}, \mathrm{K}^{+}$, and $\mathrm{Na}^{+}$) and anion $\left(\mathrm{SO}_{4}{ }^{2-}\right.$ and $\mathrm{Cl}^{-}$) concentrations in porewater collected from the upper $50 \mathrm{~cm}$ of the sites (Table 3).

$\mathrm{CH}_{4}$ emission rates from coastal wetlands are partially controlled by salinity, through the influence of $\mathrm{SO}_{4}{ }^{2-}$ [Cicerone and Oremland, 1988], resulting in annual $\mathrm{CH}_{4}$ emissions of $<1$ to $213 \mathrm{~g} \mathrm{~m}^{-2}$ in eastern and southern United States [e.g., Bartlett et al., 1985; 1987]. In the Hudson Bay lowland transect, $\mathrm{CH}_{4}$ emission rates were low $\left(0.8 \mathrm{~g} \mathrm{~m}^{-2}\right)$ from the coastal marsh mineral soils but high $(4.0$ and $5.5 \mathrm{~g} \mathrm{~m}^{-2}$ ) from small pools developing in the depressions where organic matter was beginning to accumulate. In these emerging subarctic marshes, salt is quickly removed from the upper parts of the soil by advection and diffusion [Price and Woo, 1988] and Glooschenko and Clarke [1982] noted soil saturation paste conductivities of 5 to $40 \mathrm{mS} \mathrm{cm}$, with a decline in conductivity over the summer. Hudson Bay has a low salinity, compared to seawater, and the low concentrations of salt in the surface layers of sediment ( $5 \mathrm{~g} \mathrm{~L}^{-1}$ [Price and Woo, 1988]) suggest that $\mathrm{SO}_{4}{ }^{2-}$ concentrations in this environment do not significantly inhibit $\mathrm{CH}_{4}$ emission rates.

Rates of $\mathrm{CH}_{4}$ production and consumption have been shown to be pH dependent in laboratory incubations of peat slurries. Optimum $\mathrm{pH}$ values of 5 to 7 have been reported for subarctic and temperate peats, the lower optimum being found in peats with a low native $\mathrm{pH}$ [Dunfield et al., 1993]. Acid-tolerant methanogens and methanotrophs have been reported [e.g., Patel et al., 1990; Saha and Sen, 1989; Williams and Crawford, 1985; Wolf and Hanson, 1985]. Valentine et al. [this issue] have also noted a $\mathrm{pH}$ dependence of $\mathrm{CH}_{4}$ production from Kinosheo Lake peat samples. Using samples from the Kinosheo Lake bog and coastal fen locations, R. Knowles (personal communication, 1991) has shown that $\mathrm{CH}_{4}$ production in laboratory studies of peat slurries from the upper layers is primarily 


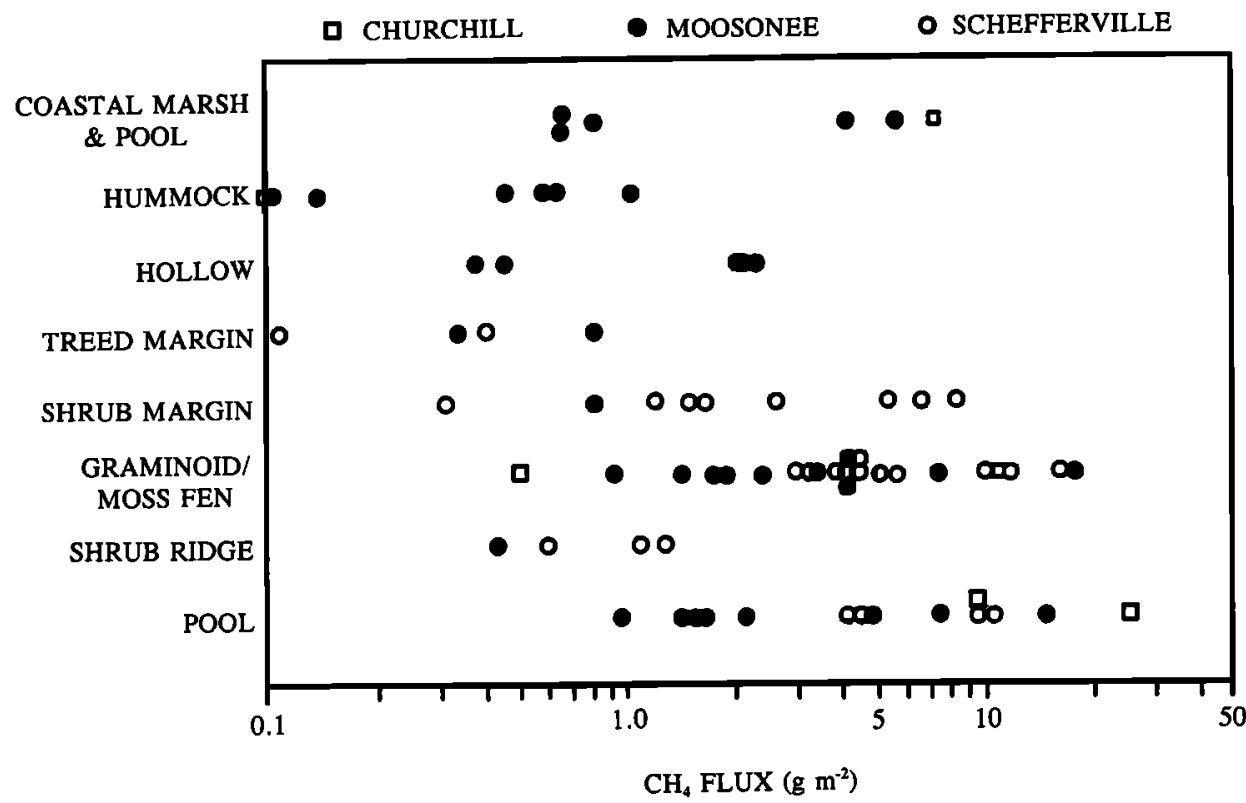

Fig. 7. Collation of estimated thaw-season $\mathrm{CH}_{4}$ emission from Canadian subarctic wetlands, based on means. Sources: Holland [1991], this paper, Moore et al. [1990], and Moore and Knowles [1990].

TABLE 3. Soil pH Values in Water, of 30 Peat Samples Used in the Incubation Experiment, and pH, Specific Conductance (S.C.) and Concentrations of $\mathrm{Ca}^{2+}, \mathrm{Mg}^{2+}, \mathrm{K}^{+}, \mathrm{Na}^{+}, \mathrm{SO}_{4}^{2+}$, and Cl, Determined on Pore-Water Samples in 0- to 25-cm depth During July and August 1990

\begin{tabular}{|c|c|c|c|c|c|c|c|c|c|c|}
\hline \multirow[b]{2}{*}{ Location \& Site } & \multirow[b]{2}{*}{$\begin{array}{l}\text { Depth, } \\
\text { cm }\end{array}$} & \multirow[b]{2}{*}{$\begin{array}{l}\text { Soil, } \\
\text { pH }\end{array}$} & \multicolumn{8}{|c|}{ Pore-Water Chemistry } \\
\hline & & & pH & $\begin{array}{l}\text { S.C. } \\
\mu \mathrm{S} \mathrm{\textrm {cm } ^ { - 1 }}\end{array}$ & $\mathrm{Ca}^{2+}$ & $\mathbf{M g}^{2+}$ & $\underset{\mathbf{m g ~ L} \mathbf{L}^{-1}}{\mathrm{~K}^{+}}$ & $\mathrm{Na}^{+}$ & $\mathrm{SO}_{4}^{2-}$ & $\mathrm{Cl}^{-1}$ \\
\hline $\begin{array}{l}\text { Coastal marsh MM } \\
\text { site } 5\end{array}$ & $\begin{array}{r}0-10 \\
10-20\end{array}$ & $\begin{array}{l}3.2 \\
7.1\end{array}$ & 7.1 & 410 & 29.3 & 20.1 & 3.3 & 112 & 17.4 & 157 \\
\hline $\begin{array}{l}\text { Coastal fen OGrF } \\
\text { site } 7\end{array}$ & $\begin{array}{r}0-10 \\
10-20\end{array}$ & $\begin{array}{l}5.6 \\
5.8\end{array}$ & 6.3 & 119 & 23.0 & 3.4 & 2.1 & 5 & 0.2 & 5 \\
\hline $\begin{array}{l}\text { Coastal fen OLsF } \\
\text { site } 6\end{array}$ & $\begin{array}{r}0-10 \\
10-20\end{array}$ & $\begin{array}{l}4.8 \\
6.1\end{array}$ & 7.0 & 65 & 43.6 & 13.9 & 5.7 & 108 & & 166 \\
\hline $\begin{array}{l}\text { Tamarack fen TLsF } \\
\text { site } 14 \text { hummock }\end{array}$ & $\begin{array}{r}0-10 \\
10-20\end{array}$ & $\begin{array}{l}4.9 \\
6.5\end{array}$ & & & & & & & & \\
\hline $\begin{array}{l}\text { Tamarack fen TLsF } \\
\text { site } 15 \text { hollow }\end{array}$ & $\begin{array}{r}0-10 \\
10-20\end{array}$ & 5.9 & 6.4 & 163 & 15.1 & 2.4 & 1.3 & 4 & 0.4 & 4 \\
\hline $\begin{array}{l}\text { Interior fen OGrF } \\
\text { site } 17\end{array}$ & $\begin{array}{r}0-10 \\
10-20\end{array}$ & $\begin{array}{l}5.3 \\
6.5\end{array}$ & & & & & & & & \\
\hline $\begin{array}{l}\text { Interior fen OGrF } \\
\text { site } 19\end{array}$ & $\begin{array}{r}0-10 \\
10-20\end{array}$ & $\begin{array}{l}5.3 \\
5.3\end{array}$ & 7.0 & 168 & 27.6 & 4.9 & 0.5 & 7 & 0.3 & 8 \\
\hline $\begin{array}{l}\text { Interior fen TLsB } \\
\text { site } 16\end{array}$ & $\begin{array}{r}0-10 \\
10-20\end{array}$ & $\begin{array}{l}3.2 \\
7.1\end{array}$ & 7.1 & 153 & 21.3 & 3.5 & 0.2 & 4 & 2.9 & 5 \\
\hline $\begin{array}{l}\text { Bog OGrB } \\
\text { site } 26\end{array}$ & $\begin{array}{r}0-10 \\
10-20\end{array}$ & $\begin{array}{l}5.2 \\
5.1\end{array}$ & & & & & & & & \\
\hline $\begin{array}{l}\text { Bog PoF } \\
\text { site } 29\end{array}$ & $\begin{array}{r}0-10 \\
10-20\end{array}$ & $\begin{array}{l}3.3 \\
3.3\end{array}$ & & & & & & & & \\
\hline $\begin{array}{c}\text { Bog PoF } \\
\text { site } 27\end{array}$ & $\begin{array}{r}0-10 \\
10-20\end{array}$ & $\begin{array}{l}3.3 \\
3.2\end{array}$ & 4.5 & 27 & 6.3 & 1.4 & 0.5 & 1 & 4.4 & 2 \\
\hline $\begin{array}{c}\text { Bog PoB } \\
\text { site } 34\end{array}$ & $\begin{array}{r}0-10 \\
10-20\end{array}$ & $\begin{array}{l}3.1 \\
3.3\end{array}$ & & & & & & & & \\
\hline $\begin{array}{l}\text { Bog TLsB } \\
\text { site } 32 \text { hummock }\end{array}$ & $\begin{array}{r}0-10 \\
10-20\end{array}$ & $\begin{array}{l}3.2 \\
3.1\end{array}$ & & & & & & & & \\
\hline $\begin{array}{l}\text { Bog TLsB } \\
\text { site } 33 \text { hollow }\end{array}$ & $\begin{array}{r}0-10 \\
10-20\end{array}$ & $\begin{array}{l}3.2 \\
3.1\end{array}$ & & & & & & & & \\
\hline $\begin{array}{l}\text { Bog TLrLsB } \\
\text { site } 31\end{array}$ & $\begin{array}{r}0-10 \\
10-20\end{array}$ & $\begin{array}{l}3.3 \\
3.2\end{array}$ & 4.5 & 43 & 9.1 & 2.3 & 0.2 & 1 & 0.9 & 1 \\
\hline
\end{tabular}


TABLE 4. Comparison of Net Primary Plant Production (NPP) [From Innanen, 1991] and Seasonal $\mathrm{CH}_{4}$ Emission for Various Sites

\begin{tabular}{|c|c|c|c|c|c|c|}
\hline Location & Site Types & $\begin{array}{c}\text { Bryophyte Biomass } \\
\text { Accumulation, } \\
\mathrm{g} \mathrm{m}^{-2}\end{array}$ & $\begin{array}{c}\text { Vascular Plant } \\
\text { Biomass } \\
\text { Accumulation, } \mathrm{g} \mathrm{m}^{2}\end{array}$ & $\begin{array}{c}\text { Total NPP } \\
\quad \mathrm{g} \mathrm{C} \mathrm{m}^{-2}\end{array}$ & $\begin{array}{c}\mathrm{CH}_{4} \\
\text { Emission } \\
\mathrm{g} \mathrm{CH}_{4} \mathrm{~m}^{-2}\end{array}$ & $\mathrm{CH}_{4}-\mathrm{C} / \mathrm{NPP}-\mathrm{C}$ \\
\hline $\begin{array}{r}\text { Coastal } \\
\text { marsh }\end{array}$ & MM $(1-5)$ & - & $218 \pm 54$ & $87 \pm 22$ & $0.63 \pm 0.62$ & 0.007 \\
\hline $\begin{array}{l}\text { Coastal } \\
\text { fen }\end{array}$ & $\begin{array}{c}\text { OLsF (6) \& } \\
\text { OGrF (7) }\end{array}$ & - & $68 \pm 17$ & $27 \pm 7$ & $0.25 \pm 0.20$ & 0.009 \\
\hline $\begin{array}{l}\text { Interior } \\
\text { fen }\end{array}$ & $\begin{array}{l}\text { OLsF }(17) \& \\
\text { OGrF }(18,19)\end{array}$ & $154 \pm 55$ & $33 \pm 17$ & $75 \pm 29$ & $0.31 \pm 0.12$ & 0.004 \\
\hline $\begin{array}{c}\text { Leduc } \\
\text { bog }\end{array}$ & $\begin{array}{l}\text { PoF } \\
(26,27,29)\end{array}$ & $70 \pm 40$ & $18 \pm 9$ & $35 \pm 20$ & $0.84 \pm 0.33$ & 0.020 \\
\hline
\end{tabular}

related to $\mathrm{H}_{2}$ availability, rather than acetate, though Valentine et al. [this issue] have noted a $\mathrm{CH}_{4}$ production response to ethyl alcohol, as an acetate precursor or electron source.

Although these laboratory studies suggest that $\mathrm{CH}_{4}$ production and consumption should decrease with a decrease in soil $\mathrm{pH}$, there is no evidence that soil $\mathrm{pH}$ plays an important role in determining the field emission of $\mathrm{CH}_{4}$ to the atmosphere. The largest field emissions were recorded at the moss/sedge mats and degrading pools at the bog locations, where the surface $\mathrm{pH}$ values are $<4.0$ and the laboratory methane production and consumption potentials were high in acidic samples.

Above ground plant net primary productivity at the wetland sites along the transect ranged from 50 to $200 \mathrm{~g} \mathrm{~m}^{-2}$ [Innanen, 1991] (Table 4). Thus $\mathrm{CH}_{4}-\mathrm{C}$ emissions are very small, ranging from 0.4 to $2.0 \%$ when expressed as a percentage of NPP-C ratios, with most sites falling into the lower end of this range. These percentages are generally lower than those quoted by Aselmann and Crutzen [1989].

\section{CONCLUSIONS}

Emissions of $\mathrm{CH}_{4}$ from wetlands in the southern section of the Hudson Bay Lowland are characterized by high variability, both spatially within and between sites, as well as temporal over the thawed season. Although $\mathrm{CH}_{4}$ emission variations over the season were poorly related to simple variables such as water table and peat temperature, the integrated flux over the thaw season at sites was significantly related to the mean seasonal position of the water table. Seasonal fluxes ranged from 0.1 to $16.6 \mathrm{~g} \mathrm{CH}_{4} \mathrm{~m}^{-2}$, and these are likely to underestimate the annual flux by up to $20 \%$. These values are generally smaller than has been assumed in the earlier construction of global $\mathrm{CH}_{4}$ budgets [e.g., Aselmann and Crutzen, 1988; Matthews and Fung, 1987), though the high spatial and temporal variability and year-to-year variations in $\mathrm{CH}_{4}$ flux introduce large errors into global extrapolations. Roulet et al. [this issue] show that the size of the northern wetlands $\mathrm{CH}_{4}$ source, using data from this study, is similar to that attributed in the recent budget of Fung et al. [1991].

These Hudson Bay lowland $\mathrm{CH}_{4}$ emission rates fall within the range observed in other northern Canadian wetlands, such as at Schefferville, Quebec and Churchill, Manitoba [Holland, 1991; Moore and Knowles, 1990; Moore et al., 1990] (Figure 7), as well as those from other arctic locations [e.g., Bartlett et al., 1992; Morrissey and Livingston, 1992; Sebacher et al., 1986; Whalen and
Reeburgh, 1988, 1990, 1992]. Although the same overall controls of water table and temperature are dominant and with similar smallscale variability in fluxes, the Arctic fluxes tend to be larger than those observed in the subarctic locations. Within the Hudson Bay lowland the $\mathrm{CH}_{4}$ emissions at Churchill, at the boundary between the subarctic and Arctic, are somewhat larger than those in the southern section. Fluxes are related to the evolution of the wetland ecosystems, through its control on thermal and hydrologic regimes and vegetation characteristics and productivity, with the largest fluxes observed at sites where the peat appears to be degrading to form shallow pools. Studies in the Alaskan tundra [Bartlett et al., 1992; Morrissey and Livingston, 1992; Whalen and Reeburgh, 1992] also suggest that $\mathrm{CH}_{4}$ emission rates are largest at the dynamic boundary between terrestrial peatland and aquatic ecosystems.

Acknowledgments. The authors gratefully acknowledgethe field assistance of Sally Innanen, Angela Travis, and Lesley Rigg and the laboratory assistance of Rosemary Ash for data analysis and Mike Dalva for incubation experiments. John Riley of the Ontario Ministry of Natural Resources provided floristic identifications at the site and discussed the ecological setting of the transect. Bob McCrea of the Canadian Centre for Inland Waters kindly analyzed pore-water samples for nutrients. This is Scientific Contribution 92-16 of the Canadian Institute for Research in Atmospheric Chemistry (CIRAC). The work described was undertaken as part of the Northern Wetlands Study, which has been generously supported by the Natural Sciences and Engineering Research Council of Canada.

\section{REFERENCES}

Aselmann, I., and P.J. Crutzen, Global distribution of natural freshwater wetlands and rice paddies, their net primary productivity, seasonality and possible methane emissions, J. Atmos. Chem., 8, 307-358, 1989.

Bartlett, D., G. Sachse, P. Bakwin, K. Bartlett, D. Fitzjarrald, and G. Whiting, Regional flux estimates from synthesis of enclosure, tower and aircraft measurements (abstract), Eos Trans. $A G U, 70$ (3), 286, $1989 a$.

Bartlett, D.S., K.B. Bartlett, J.M. Hartman, R.C. Harriss, D.I. Sebacher, R. Pelletier-Travis, D.D. Dow, and D.P. Bannon, Methane emissions from the Florida Everglades: Patterns of variability in a regional wetland ecosystem, Global Biogeochem. Cycles, 3, 363-374, $1989 b$.

Bartlett, K.B., R.C. Harriss, and D.I. Sebacher, Methane flux from cosstal marshes, J. Geophys. Res., 90, 5710-5720, 1985.

Bartlett, K.B., D.S. Bartlett, R.C. Harriss, and D.I. Sebacher, Methane emissions along a salt marsh salinity gradient, Biogeochem., 4, 183-202, 1987.

Bartlett, K.B., P.M. Crill, R.L. Sass, R.C. Harriss, and N.B. Dise, Methane emissions from tundra environments in the Yukon-Kuskokwim Delta, Alaska. J. Geophys. Res., 97, 16,645-16,660, 1992. 
Cicerone, R.J., and R.S. Oremland, Biogeochemical aspects of atmospheric methane, Global Biogeochem. Cycles, 2, 299- 327, 1988.

Crill, P.M., K.B. Bartlett, R.C. Harriss, E. Gorham, E.S. Verry, D.I. Sebacher, L. Madzar, and W. Sanner, Methane flux from Minnesota peatlands, Global Biogeochem. Cycles, 2, 371-384, 1988.

Dise, N.B., Winter fluxes of methane from Minnesota peatlands, Biogeochem., in press, 1992.

Dise, N.B., Methane emission from Minnesota peatlands: Spatial and seasonal variability, Global Biogeochem. Cycles, 7, 123-142, 1993.

Dunfield, P., R. Knowles, R. Dumont, and T. Moore, Methane production and consumption in temperate and subarctic peat soils: Response to temperature and pH, Soil Biol. Biochem., 23, 321-326, 1993.

Fung, I., J. John, J. Lerner, E. Matthews, M. Prather, L. Steele, and P. Fraser, Global budgets of atmospheric methane: Results from a threedimensional global model synthesis, J. Geophys. Res., 96, 13,033-13,065, 1991.

Glooschenko, W.A., Above-ground biomass of vascular plants in a subarctic James Bay salt marsh, Canadian Field Naluralist, 92, 30-37, 1978.

Glooschenko, W.A., and K. Clarke, The salinity cycle of a subarctic salt marsh, Nat. Can., 109, 483-490, 1982.

Glooschenko, W.A., N.T.Roulet, L.A. Barrie, H.I. Schiff and H.G McAdie, The Northern Wetlands Study (NOWES): An overview, J. Geophys. Res., this issue.

Hamilton, J.D., C.A. Kelly, J.W. Rudd, and R.H. Hesslein, Flux to the atmosphere of $\mathrm{CH}_{4}$ and $\mathrm{CO}_{2}$ from wetland ponds on the Hudson Bay lowlands (HBL), J. Geophys. Res., this issue.

Harriss, R., K. Bartlett, S. Frolking, and P. Crill, Methane emissions from northern high latitude wetlands, in Proceedings, International Symposium on Environmental Biogeochemistry, edited by R.S. Oremland, pp. 449. 486, Chapman and Hall, New York, 1993.

Holland, S., Methane Emissions from Wetlands in the High Subarctic Region of the Hudson Bay Lowland, M.Sc. Thesis, McMaster University, Hamilton, Ontario, 1991.

Innanen, S.E.R., Productivity of Vascular and Non-vascular Plants along a $100 \mathrm{~km}$ Transect in the Hudson Bay Lowland, B.Sc. Thesis, Department of Geography, York University, North York, Ontario, 1991.

King, G.M., Regulation by light of methane emissions from a wetland, Nature, 345, 513-514, 1990.

King, G.M., P. Roslev, and H. Skovgaard, Distribution and rate of methane oxidation in sediments of the Florida Everglades, Appl. Environ. Microbiol., 56, 2902-2911, 1990.

Klinger, L., P. Zimmerman, J.P. Greenberg, L.E. Heidt, and A.B. Guenther, Carbon trace gas fluxes along a successional gradient in the Hudson Bay lowland, J. Geophys. Res., this issue.

Matthews, E., and I. Fung, Methane emission from natural wetlands: Global distribution, area and environmental characteristics of sources, Global Biogeochem. Cycles, 1, 61-86, 1987.

Moore, T.R., Thermal regime of peatlands in subarctic eastern Canada, Can. J. Earth Sci., 24, 1352-59, 1987.

Moore, T.R., and R. Knowles, Methane emissions from fen, bog, and swamp peatlands in Quebec, Biogeochemistry, 11, 45-61, 1990.

Moore, T.R., and N.T. Roulet, A comparison of dynamic and static chambers for methane emission measurements from subarctic fens, Atmos.-Ocean, 29, 102-109, 1991.

Moore, T.R., and N.T. Roulet, Methane flux:water table position relations in northern peatlands, Geophys. Res. Lett., 20, 587-590, 1993.

Moore, T., N. Roulet, and R. Knowles, Spatial and temporal variations of methane flux from subarctic/northern boreal fens, Global Biogeochem. Cycles, 4, 29-46, 1990.

Morrissey, L.A., and G.P. Livingston, Methane emissions from Alaskan Arctic Tundra: An assessment of local spatial variability, J. Geophys. Res., 97, 16,661-16,670, 1992.

Mortsch, L., Eastern Canadian boreal forest and sub-arctic wetlands:
Resource document. Climatol. Stud. 42, 168 pp., Atmos. Environ. Serv., Environ. Can., Downsview, Ont., 1990.

Mortsch, L., Assessment of the climate of 1990 during the Northern Wetlands Study (NOWES), J. Geophys. Res., this issue.

National Wetlands Working Group, Wetlands of Canada, Polyscience Publications, Montreal, 1988.

Patel, G.B., G.D. Sprott, and J.E. Fein, Isolation and characterization of Methanobacterium espanolae sp. nov., a mesophilic, moderately acidiphilic methanogen, Int. J. Syst. Bacteriol., 40, 12-18, 1990.

Price, J.S., and M-K. Woo, Studies of a subarctic coastal marsh, II, salinity, J. Hydrol., 103, 293-307, 1988.

Riley, J.L., Hudson Bay lowland floristic inventory, wetlands catalogue and conservation strategy, Nat. Can., 109, 543-555, 1982.

Roulet, N.T., Role of the Hudson Bay Lowland as a source of atmospheric methane (abstract), Eos Trans. AGU, 72 (17), 84, 1991.

Roulet, N.T., R. Ash, and T.R. Moore, Low boreal wetlands as a source of atmospheric methane, J. Geophys. Res., 97, 3,739-3,749, 1992.

Roulet, N.T., A. Jano, C.A. Kelly, L. Klinger, T.R. Moore, R. Protz, J.A. Ritter, and W.R. Rouse, The role of the Hudson Bay lowland as a source of atmospheric methane, J. Geophys. Res., this issue.

Saha, V., and M. Sen, Methane oxidation by Candida tropicalis, Nat. Acad. Sci. Lett., 12, 373-376, 1989.

Sebacher, D.I, R.C. Harriss, and K.B. Bartlett, Methane flux across the airwater interface: Air velocity effects, Tellus, 35B, 103-109, 1983.

Sebacher, D.I., R.C. Harriss, K.B. Bartlett, S.M. Sebacher, and S.S. Grice, Atmospheric methane sources: Alaskan tundra bogs, an alpine fen, and a subarctic boreal marsh, Tellus, 38B, 1-10, 1986.

Valentine, D.W., E.A. Holland, and D.S. Schimel, Ecosystem and physiological controls over methane production in northern wetlands, $J$. Geophys. Res., this issue.

Whalen, S.C., and W.S. Reeburgh, Methane flux time-series for tundra environments, Global Biogeochem. Cycles, 2, 399-409, 1988.

Whalen, S.C., and W.S. Reeburgh, Consumption of atmospheric methane by tundra soils, Nature, 346, 160-162, 1990.

Whalen, S.C., and W.S. Reeburgh, Interannual variations in methane emissions: A four-year time series at fixed sites, Global Biogeochem. Cycles, 6, 139-159, 1992.

Whalen, S.C., W.S. Reeburgh, and C.E. Reimers, Control of tundra methane emission by microbial oxidation, in Landscape Function: Implications for Ecosystem Response to Disturbance, A Case Study in Arctic Tundra, edited by J.F. Reynolds and J.D. Tenhunen, SpringerVerlag, New York, in press, 1993.

Whiting, G.J., and J.P. Chanton, Plant-dependent $\mathbf{C H}_{4}$ emission in a subarctic Canadian fen, Global Biogeochem. Cycles, 6, 225-231, 1992.

Williams, R.T., and R.L. Crawford, Methanogenic bacteria, including an acid-tolerant strain, from peatlands, Appl. Environ. Microbiol, , 50: 1542$1544,1985$.

Windsor, J., T.R. Moore, and N.T. Roulet, Episodic fluxes of methane from subarctic fens, Can. J. Soil Sci., 72, 441-452, 1992.

Wolf, H.J., and R.S. Hanson, Identification of methane-utilizing yeasts, FEMS Microbiol. Lett., 50, 1542-1544, 1985.

Yavitt, J.B., G.E. Lang, and R.K. Wieder, Control of carbon mineralization to $\mathrm{CH}_{4}$ and $\mathrm{CO}_{2}$ in anaerobic, Sphagnum-derived peat from Big Run Bog, West Virginia, Biogeochemistry, 4, 141-157, 1987.

T.R. Moore and A. Heyes, Department of Geography and Centre for Climate and Globai Change Research, McGill University, 805 Sherbrooke St. W., Montreal, Québec, Canada H3A 2K6.

N.T. Roulet, Department of Geography, York University, 4700 Keele St., North York, Ontario, Canada M3J 1 P3.

(Received May 26, 1992: revised August 23, 1993; accepted August 25, 1993.) 